\title{
Gambaran Pendapatan Orang Tua dan Kekerasan pada Anak dalam Keluarga di Gampong Geulanggang Teungoh Kecamatan Kota Juang Kabupaten Bireuen
}

\author{
Siti Maryam \\ Staf Pengajar Fakultas Kedokteran Universitas Malikussa \\ e-mail : sitimaryam_ipb@yahoo.com
}

\begin{abstract}
The violence on children in the household is often happened compared to other violence, involving the father, mother, brother, and others. In addition, the violence also arise due to economic pressures. Parents' education and low-income are some factors that can trigger violence experienced by children. This study aimed to describe the family income and child abuse occurring within the family in the Gampong Geulanggang Teungoh, Kecamatan Kota Juang, Kabupaten Bireuen. The results showed that most of the family income (60\%) are above the minimum wage of Aceh province. In addition, the results also showed that almost all types of violence experienced by the children, except sexual violence.
\end{abstract}

Keywords: income, parenting, children violence 


\section{PENDAHULUAN}

Keluarga merupakan tempat pertama bagi anak untuk memperoleh pembinaan mental dan pembentukan kepribadian. Keluarga memiliki peran dan fungsi yang cukup besar terhadap perkembangan dan masa depan anak. Seorang anak harus mendapatkan kesempatan yang seluas-luasnya untuk dapat tumbuh dan berkembang secara optimal baik fisik, psikis, sosial, maupun spiritual. Anak juga perlu mendapatkan hak-haknya untuk dilindungi dan disejahterakan. Segala bentuk tindak kekerasan terhadap anak perlu dicegah dan diatasi sebagaimana tercantum dalam Undang-Undang Republik Indonesia nomor 23 Tahun 2002 tentang Perlindungan Anak, bahwa anak harus mendapatkan perlindungan dan dipenuhi hak-haknya untuk tumbuh dan berkembang secara normal, dan anak diberikan kesempatan berpartisipasi secara optimal serta mendapat perlindungan dari kekerasan dan diskriminasi (Harjosumantri, 2003).

Munculnya kekerasan pada anak dalam rumah tangga sering terjadi, antara lain kekerasan yang melibatkan pihak ayah, ibu dan saudara yang lainnya. Selain itu, kekerasan juga timbul karena tekanan ekonomi karena ketidakmampuan keluarga untuk memenuhi kebutuhan anggota keluarganya. Sebagai orang tua, pendidikan yang utama dan pertama memegang peranan yang paling penting, agar anak tidak terpengaruh pada lingkungan yang tidak baik yang dapat memicu anak tersebut untuk melakukan tindakan kekerasan. Seperti yang sampaikan Menteri Pendidikan dan Kebudayaan, model-model video game kekerasan itu yang harus menjadi perhatian orang tua.

Ada berbagai kemungkinan penyebab kecenderungan terjadinya kekerasan pada anak. Pendidikan dan pendapatan orang tua yang rendah merupakan salah satu faktor yang dapat memicu terjadi tingkat kekerasan yang dialami anak. Di samping itu, kurangnya pengetahuan dan wawasan yang berhubungan dengan pengasuhan, pertumbuhan, dan perkembangan anak juga menyebabkan orang tua sering memperlakukan anak secara salah. Harapan orang tua yang terlalu tinggi tanpa mengenal keterbatasan anak dan pandangan orang tua bahwa anak adalah hak milik orang tua atau merupakan aset ekonomi menyebabkan orang tua tidak mengetahui kebutuhan dan kemampuan anak, sehingga orang tua selalu memaksakan kehendaknya terhadap anak. Anak Indonesia pada usia 6-12 tahun paling sering mengalami kekerasan seksual (33\%) dan emosional (28,8\%), dibandingkan dengan kekerasan yang bersifat fisik $(24,1 \%)$. Ruang kekerasan terhadap anak sebagian besar terjadi di rumah (129 kasus), selanjutnya di jalanan (79 kasus), sekolah (10 kasus), lembaga keagamaan (2 kasus), sektor perekonomian (21 kasus). Kekerasan seksual juga terjadi tidak hanya di rumah $(48,7 \%)$, tapi juga di tempat umum $(6,1 \%)$, sekolah $(4,1 \%)$, tempat kerja (3,0\%), lain-lain $(0,4 \%)$ (Sochib, 2005).

Pusat pelayanan terpadu

Pemberdayaan Perempuan dan Anak (P2TP2A) mencatat adanya 2.470 kasus kekerasan terhadap perempuan dan anak yang terjadi di Provinsi Aceh dalam tiga tahun terakhir dan 1.400 kasus terjadi kekerasan terhadap anak. AKBP Evianti dari unit Pelayanan Perempuan dan Anak (PPA) Polda Aceh menyatakan ada 364 kasus kekerasan yang terjadi sepanjang tahun 2013, dari sejumlah kasus kekerasan yang masuk ke pihak kepolisian, 4 sampai 5 kasus didominasi kekerasan terhadap perempuan dan anak, lebih lanjut Evianti 
mengemukakan, dari sejumlah korban kekerasan, sebagian besar adalah anak di bawah umur atau di bawah usia 12 tahun, sementara pelakunya adalah orang-orang yang terdekat, seperti orang tua, paman, tetangga dan oknum guru. Dari laporan yang sudah masuk kepada lingkungan Polresta, Banda Aceh menempati urutan pertama, disusul Aceh Besar, Singkil dan Bireuen. Peningkatan jumlah kasus yang masuk bukan semata-mata kasus meningkat, tapi juga kesadaran masyarakat dalam melaporkan sudah meningkat (Solihin, 2014).

Berdasarkan data yang diperoleh dari unit Perlindungan Perempuan dan Anak (PPA) Kabupaten Bireuen, kekerasan terhadap anak terus meningkat tiap tahunnya. Pada tahun 2013 kekerasan terhadap anak dan perempuan berada pada angka 101 kasus, sementara pada tahun 2014 terus meningkat menjadi 123 kasus. Berdasarkan data dari badan Pemberdayaan Perempuan dan keluarga Kabupaten Bireuen, kekerasan dalam rumah tangga (KDRT) dari 26 kasus pada 2013 menjadi 45 kasus pada tahun 2014, sementara trafficking dari 5 kasus menurun menjadi 3 kasus, pemerkosaan dari 41 kasus menurun menjadi 13 kasus, pencabulan dari 2 kasus menjadi 15 kasus, penelantaran anak masih sama antara tahun 2013 dan 2014 ada 2 kasus, penganiayaan dari 6 kasus menurun menjadi 5 kasus, kekerasan terhadap perempuan meningkat dari 9 kasus menjadi 19 kasus, dan kekerasan terhadap anak meningkat dari 9 kasus menjadi 19 kasus tahun 2014. (Kompasiana. 2014)

Dari hasil survey awal yang dilakukan di di Gampong Geulanggang Teungoh, Kecamatan Kota Juang, Kabupaten Bieuen, kejadian kekerasan pada anak dari tahun 2014 tercatat sebanyak 9 kasus, diantaranya 6 kasus pemukulan terhadap anak dan 3 kasus penelantaran.
Berdasarkan informasi tersebut penulis ingin mengetahui lebih dalam bagaimana gambaran pendapatan keluarga dan kekerasan pada anak yang terjadi dalam keluarga di Gampong Geulanggang Teungoh, Kecamatan Kota Juang, Kabupaten Bieuen.

Berdasarkan uraian latar belakang masalah di atas maka yang menjadi rumusan masalah dalam penelitian ini adalah bagaimanakah gambaran pendapatan orang tua dan kekerasan pada anak yang terjadi dalam keluarga di Gampong Geulanggang Teungoh, Kecamatan Kota Juang, Kabupaten Bieuen.

Penelitian ini bertujuan untuk mengetahui "Gambaran Pendapatan Orang Tua dan Kekerasan pada Anak yang Terjadi dalam Keluarga di Gampong Geulanggang Teungoh, Kecamatan Kota Juang, Kabupaten Bireuen”.

\section{METODE}

Metode penelitian adalah cara yang digunakan oleh peneliti dalam mengumpulkan data penelitian (Arikunto, 2010). Metode penelitian yang digunakan adalah penelitian deskriptif, yaitu penelitian yang bertujuan menggambarkan keadaan yang sebenarnya. Untuk memperoleh data yang objektif maka digunakan bentuk penelitian lapangan (field reserch). Penelitian lapangan dilakukan untuk memperoleh data-data lapangan langsung dengan cara mendatangi masyarakat (responden) yang akan diteliti (Notoadmojo, 2005). Penelitian telah diadakan di Gampong Geulanggang Teungoh, Kabupaten Bieuen dan telah dilaksanakan pada bulan Agustus 2015.

Populasi dalam penelitian ini adalah keluarga yang mempunyai anak yang berumur di bawah 18 tahun. Jumlah populasi adalah 130 orang, dan sampel 
yang memenuhi kriteria dalam penelitian ini sebanyak 50 orang.

Teknik Pengumpulan Data

Adapun penelitian yang dilakukan oleh penulis adalah penelitian lapangan (field research), yaitu penelitian yang dilakukan dengan terjun langsung ke objek penelitian. Untuk memperoleh datadata lapangan ini penulis menggunakan teknik pengumpulan data sebagai berikut: Observasi atau pengamatan merupakan suatu prosedur yang berencana yang meliputi melihat dan mencatat jumlah dan taraf aktivitas tertentu yang ada hubungannya dengan masalah yang diteliti (Notoadmodjo, 2005). Observasi ini dilakukan untuk memperoleh data tentang kondisi umum rumah tangga (keluarga) di Gampong Geulanggang Teungoh, Kabupaten Bieuen.

Angket atau kuesioner, adalah sejumlah pertanyaan tertulis yang digunakan untuk memperoleh informasi dari responden dalam arti laporan tentang pribadinya atau hal-hal yang ia ketahui (Arikunto, 2010). Angket yang digunakan adalah tipe pilihan (tertutup).

Data yang telah dikumpulkan dikelompokkan menurut peubahnya, kemudian ditabulasi dan dianalisis secara deskriptif

\section{HASIL}

Pendapatan keluarga adalah pendapatan yang diperoleh ayah, ibu dan anggota keluarga lainnya. Sebaran pendapatan keluarga tertera pada Tabel 3.1

Tabel 3.1.

Sebaran Tingkat Pendapatan Keluarga di Gampong Geulanggang Teungoh, Kecamatan Jeumpa, Kabupaten Bieuen

\begin{tabular}{lll}
\hline $\begin{array}{l}\text { Tingkat } \\
\text { Pendapatan }\end{array}$ & $\begin{array}{l}\text { Kategori } \\
\text { Jawaban }\end{array}$ & Persentase \\
\hline$<1.750 .000$ & 20 & $40 \%$ \\
$\geq 1.750 .000$ & 30 & $60 \%$ \\
\hline Jumlah & 50 & $100 \%$ \\
\hline
\end{tabular}

Tabel di atas menunjukkan bahwa 20 orang $(40 \%)$ yang memiliki tingkat pendapatan $<1.750 .000$, sedangkan 30 orang $(60 \%)$ yang memiliki tingkat pendapatan $\geq 1.750 .000$. Berdasarkan analisis data di atas maka, dapat disimpulkan bahwa tingkat pendapatan masyarakat desa Geulanggang Teungoh lebih banyak di atas UMR Provinsi Aceh.

Salah satu penyebab terjadinya kekerasan pada anak karena orang tua tidak tidak mampu memenuhi kebutuhan anak, sehingga anak dipaksa untuk bekerja untuk membantu orang tuanya. Sebaran kekerasan pada anak dapat dilihat pada

Tabel 3.2.

Frekuensi Kekerasan pada Anak di Gampong Geulanggang Teungoh, Kecamatan Jeumpa, Kabupaten Bieuen

\begin{tabular}{lllll}
\hline Bentuk Kekerasan & Ya & $(\%)$ & Tidak & $(\%)$ \\
\hline $\begin{array}{l}\text { Kekerasan Fisik } \\
\text { Kekerasan }\end{array}$ & 35 & 70 & 15 & 30 \\
Emosional & 50 & 100 & 0 & 0 \\
$\begin{array}{l}\text { Kekerasan Verbal } \\
\text { Kekerasan Seksual }\end{array}$ & 0 & 0 & 50 & 100 \\
$\begin{array}{l}\text { Kekerasan } \\
\text { Ekonomi }\end{array}$ & 49 & 98 & 1 & 2 \\
\hline
\end{tabular}

Berdasarkan tabel di atas dapat diketahui bahwa tingkat kekerasan yang dialami oleh anak cukup tinggi. Hampir semua jenis kekerasan dalam keluarga pernah dilakukan orang tua, kecuali kekerasan seksual. 


\section{DISKUSI}

Pendapatan adalah jumlah penghasilan yang diterima oleh para anggota masyarakat untuk jangka waktu tertentu sebagai balas jasa atas faktorfaktor produksi yang mereka sumbangkan dalam turut serta membentuk produk nasional. Menurut Reksoprayitno pendapatan atau income adalah uang yang diterima oleh seseorang dan perusahaan dalam bentuk gaji, upah, sewa bunga, dan laba termasuk juga beragam tunjangan, seperti kesehatan dan pension (Reksoprayitno, 2009). Pendapatan keluarga adalah jumlah penghasilan riil dari seluruh anggota rumah tangga yang digunakan untuk memenuhi kebutuhan bersama maupun perseorangan dalam rumah tangga. Pendapatan keluarga merupakan balas karya atau jasa atau imbalan yang diperoleh karena sumbangan yang diberikan dalam kegiatan produksi. Berdasarkan hasil penelitian menunjukkan bahwa $60 \%$ kepala keluarga berpenghasilan di atas UMR Provinsi Aceh yaitu $>\mathrm{Rp}$ 1750.000/bulan, walaupun masih ada $40 \%$ keluarga yang berpenghasilan di bawah UMR Provinsi Aceh. Pendapatan keluarga yang rendah akan berpengaruh kepada pemenuhan kebutuhan anggota keluarga, Dengan kondisi pendapatan keluarga yang rendah secara tidak langsung memaksa anak untuk bekerja dengan tujuan menambah penghasilan keluarga. Anak yang dipaksa bekerja sebelum waktunya adalah bentuk kekerasan dalam bidang ekonomi.

Tindak kekerasan terhadap anak memang kerap terjadi. Lebih parah lagi pelaku tindak kekerasan tersebut berasal dari keluarga korban sendiri, seperti orang tua atau guru di sekolah. Rendahnya pendidikan dan perhatian orang tua serta minimnya pengetahuan cara mendidik anak yang benar, akan berdampak terhadap perilaku orang tua dalam memberikan pengasuhan kepada anak. Kurangnya partisipasi orang tua dalam program parenting mengakibatkan orang tua tidak memahami betapa pentingnya pengasuhan itu bagi orang tua agar kita bisa mendewasakan anak secara lebih manusiawi. Pendidikan dan pengasuhan merupakan amanat yang diemban oleh para orang tua yang senantiasa perlu kreativitas dan inovasi yang tak kenal henti. Dunia terus berkembang dalam skala yang tak terprediksi. Maka mendidik anakpun bermakana menyiapkan anak untuk sebuah masa depan yang lebih maju. Mendidik dan mengasuh itu menjadi prioritas dalam keseharian, memberikan mereka waktu luang dengan kualitas yang baik. Predikat orang tua yang baik baru bisa disandang bila sudah mendidik dan mengasuh anak dengan upaya terbaik dan menghasilkan karakter dan perilaku anak yang baik pula.

Sebagai orang tua kita harus memahami bagaimana karakter dan potensi yang dimiliki anak-anak kita. Sudah menjadi kewajiban para orang tua untuk membekali anak-anaknya dengan pengetahuan dan keterampilan yang menunjang bakat dan potensinya, sehingga orang tua tidak selalu memaksakan kehendaknya di luar kapasitas yang dimilikinya (Gordon 2003). Pemaksaan kehendak orang tua terhadap anak juga merupakan tindakan kekerasan, contohnya anak dipaksa untuk mencari uang untuk memenuhi kebutuhan keluarga, yang seharusnya anak bermain dan bersekolah.

Berdasarkan hasil menunjukkan bahwa anak-anak yang kerap mendapat kekerasan, baik fisik, emosional, dan kekerasan ekonomi. Kekerasan yang dialami anak secara spontan akan berpengaruh pada otak kecilnya (alam bawah sadar). Anak yang awalnya mendapat kekerasan hanya diam saja, 
ketika kekerasan oleh orang tua itu dilakukan bertubi-tubi, anak melakukan pembelaan diri dan bersikap agresif. Kekerasan direkam anak dalam otak kecilnya. Ketika anak-anak ini menginjak dewasa dan ia mengalami tekanan jiwa yang menyebabkan ia marah, memori masa kecil di mana anak kerap mendapat kekerasan memacunya untuk melakukan kekerasan yang sama, melakukan hal yang dialaminya ketika masa kecilnya.

Dalam penelitian ini ditemukan bahwa sebagian besar orang tua sering melakukan kekerasan fisik pada anak secara spontan dan dengan volume yang sering. Sebagian besar keluarga tidak memahami bahwa anak harus mendapat pengasuhan tanpa kekerasan. Fenomena kekerasan di keluarga seakan lumrah, biasa dan dibenarkan oleh kultur. Anak menjatuhkan makanan, anak merengek minta mainan, anak lari-larian dan hal-hal kecil yang dilakukan kerapkali memicu orang tua marah dan melakukan kekerasan secara fisik. Bentakan dan pukulan sering dialamatkan kepada anak dengan berlindung pada dalih agar anak disiplin dan tidak manja. Berangkat dari "marah" itulah sebagian besar orang tua melakukan kekerasan fisik dan psikis kepada anak. Dalam buku pedoman "Mari Kita Akhiri Kekerasan Pada Anak" terbitan Indonesia Heritage Foundation tahun 2008 dijelaskan bagaimana marah dan kekerasan orang tua kepada anaknya dalam pola pengasuhan berdampak buruk pada jangka panjang.

Proses tumbuhnya budaya kekerasan dalam masyarakat sama dengan proses pembentukan persepsi dalam diri masyarakat. Proses tumbuhnya budaya kekerasan dimulai dari penginderaan atas kekerasan yang terjadi lingkungan. Penginderaan yang terjadi secara massif mempengaruhi otak kecil anak dan terekam secara permanen. Rekaman kekerasan ini membutuhkan ruang aktualisasi ketika anak tersebut dalam kondisi tertekan jiwanya. Proses penginderaan atas tindak kekerasan seperti ini mirip dengan proses pembentukan persepsi dalam diri manusia. Drever dalam Sasanti (2003) mendefinisikan persepsi sebagai suatu proses pengenalan atau identifikasi sesuatu dengan menggunakan panca indera. Kesan yang diterima individu sangat tergantung pada seluruh pengalaman yang telah diperoleh melalui proses berpikir dan belajar, serta dipengaruhi oleh faktor yang berasal dari dalam diri individu.

Kekerasan menyebabkan perkembangan fisik dan psikis dari korban terguncang dibutuhkan penyembuhan untuk memupuk rasa percaya diri dan bangkit dari keterpurukan. Anak-anak yang telah mengalami kekerasan memerlukan kasih dan perhatian yang ekstra dari lingkungannya. Kepedulian dan keramahan dari saudara, teman-teman dan guru sangat dibutuhkan demi membantu anak mengatasi traumanya guna menata kehidupan di masa depan.

\section{DAFTAR PUSTAKA}

Arikunto, S. 2010. Prosedur Penelitian Suatu Pendekatan Praktek. Jakarta: Rineka Cipta.

Gordon, T, 2003. Menjadi orang Tua Efektif, Jakarta: P.T Gramedia Pustaka Utama

Harjosumantri, K. 2003. Hukum tata lingkungan. Yogyakarta: Universitas Gadjah Mada.

Kompasiana. 2014. Fantastis Angka Kekerasan Anak Meningkat 98\%. http://edukasi.kompasiana.com/201 1/12/22/. Diakses 1 Januari 2014. 
Notoadmodjo, S. 2005. Metodelogi Penelitian Kesehatan. Jakarta: Rineka Cipta.

Pedoman Pendidikan Karakter pada Pendidikan Anak Usia Dini, Direktorat Pembinaan Pendidikan Anak Usia Dini Ditjen PAUDNI, Kemendiknas, 2011

Pedoman Penyelenggaraan PAUD Berbasis Keluarga. Direktorat Pembinaan Pendidikan Anak Usia Dini Ditjen PAUDNI, Kemendiknas, 2011

Sochib. 2005. Pola Asuh Orang Tua Dalam Membantu Anak Mengembangkan Diri. Jakarta: Rineka Cipta.

Solihin. 2014. Tindakan Kekerasan Pada Anak Dalam Keluarga. Jakarta: Jurnal Pendidikan Penabur-No 03/Th.III/Desember.

Susianah Afandi, 2016, Kekerasan Dalam Pengasuhan Anak

Soediyono Reksoprayitno,. 2009. Ekonomi Makro. Badan Penerbit Fakultas Ekonomi (BPFE) : UGM. 